\title{
COMPARTIMENTAÇÃO GEOMORFOLÓGICA E MORFOTECTÔNICA DO GRÁBEN DO CARIATÁ, PARAÍBA, A PARTIR DE IMAGEAMENTO REMOTO
}

\author{
MORPHOTECTONIC COMPARTMENTS OF CARIATÁ GRABEN, STATE OF \\ PARAIBA, NORTHEASTERN BRAZIL, BASED ON REMOTE SENSE IMAGERY
}

\author{
Bruno Azevedo Cavalcanti Tavares \\ Departamento de Geografia, Universidade Federal do Rio Grande do Norte \\ Rua Joaquim Gregório S/N - Penedo, Caicó - Rio Grande do Norte/RN, Cep: 59078-970, Brasil \\ E-mail: brunoactavares@yahoo.com.br \\ Antonio Carlos de Barros Corrêa \\ Departamento de Ciências Geográficas, Universidade Federal de Pernambuco \\ Av. Prof. Moraes Rego, 1235 - Cidade Universitária, Recife/PE, Cep: 50670-901, Brasil \\ E-mail: dbiase2001@terra.com.br
}

Daniel Rodrigues de Lira

Departamento de Geografia, Universidade Federal de Sergipe Av. Olímpio Grande, s/n, Bloco D, Itabaiana/SE, Cep: 49100-000, Brasil

E-mail: dniellira@gmail.com

Lucas Costa de Souza Cavalcanti

Departamento de Geografia, Universidade de Pernambuco BR 203, Km 2, s/n, Petrolina/PE, Cep: 56328-903, Brasil

E-mail: lucascavalcanti3@gmail.com

Informações sobre o Artigo

Data de Recebimento:

10/04/2014

Data de Aprovação:

$14 / 08 / 2014$

Palavras-chave:

Morfotectônica, Técnicas SIG, Gráben do Cariatá, Nordeste do Brasil.

\section{Keywords:}

Morphotectonics, GIS

techniques, Cariata Graben,

Northeastern Brazil.

\section{Resumo:}

Desde a sua identificação, a unidade geomórfica Gráben do Cariatá tornou-se de fundamental importância para a interpretação do cenário morfotectônico regional no contexto do rebordo leste do nordeste do Brasil, desafiando algumas hipóteses prévias sobre a evolução geomórfica do piemonte do planalto da Borborema. Neste sentido, faz-se necessário refinar o conhecimento referente à história geomórfica desde gráben, de seus preenchimentos sedimentares, unidades pedo-estratigráficas e controles lito-estruturais sobre as associações de formas de relevo. Um estudo desta ordem pode lançar luz sobre a evolução dos compartimentos escalonados que antecedem a escarpa da Borborema e suas implicações sob pontos de vista páleo-climáticos e neotectônicos, a partir de abordagens que prescindam da utilização do conceito das superfícies regionais de aplainamento. A combinação de modelos digitais de elevação (MDE) e imagens de satélite propiciaram uma modelagem mais precisa da área de estudo, sendo uma importante ferramenta para 
a análise da influencia da neotectônica sobre a compartimentação do relevo. Desse modo, feições como escarpas, facetas triangulares, anfiteatros de erosão e vales lineares foram identificados a partir de técnicas de sensoriamento remoto e estão estritamente ligadas às linhas de reativação de falhas no gráben. A rede de drenagem principal da área de estudo, o rio Paraíba, também está influenciada pela dinâmica morfotectônica, o que se faz explicitar a partir de uma incisão de maior ordem em determinados setores, resultando no abandono da antiga planície sob a forma de terraços erosivos.

\begin{abstract}
:
Following its identification, the geomorphic unity named Cariata Graben has become capital for the interpretation of the regional morphotectonic and geomorphic context of the eastern seaboard of Northeastern Brazil, challenging some previous hypothesis that dealt with the geomorphic evolution of the Borborema highlands piedmont. In this regard, it is crucial to refine the knowledge concerning the geomorphic history of the graben, its sedimentary infill, pedo-stratigraphic units and litho-structurual controls upon the landforms assembly. A study of such magnitude may throw light on the evolution of the stepped relief compartments that antecede the escarpment of the Borborema Highlands, and its paleoclimatic and neotectonic implications, based on approaches that do not validate the traditional idea of planation surfaces. The combined application of Digital Elevation Models (DEM) and satellite imagery favored a more acurate modelling of the study area, thus representing an important tool for the analysis of neotectonic influence upon the landform compartments. In this regard, features such as escarpments, triangular facets, erosion catchments and linear valleys were identified based on an array of GIS techniques and directly linked to the reactivation of fault-lines within the Graben. It was also observed that the drainage network of the study area, commanded by the Paraiba river, is also influenced by neotectonics, which becomes explicit by the level of channel incision in some sectors, which results in the abandonment of the former fluvial plain and its erosive terraces.
\end{abstract}

\section{Introdução}

A Geomorfologia em ambientes de margem passiva tem sido interpretada a partir das teorias clássicas de evolução do relevo. (Davis, 1899; King, 1956; Bigarella e Mousinho, 1967; Mabesoone e Castro, 1975). No entanto, estudos nas últimas décadas têm trazido à tona a abordagem de pulsos tectônicos recentes controlando o relevo no contexto da plataforma sul-americana (Hasui, 1984; Saadi, 1991; Bezerra et al., 2008; 2011; Maia e Bezerra, 2014). Essa abordagem, baseada numa tectônica cenozoica, recai na questão da morfotectônica e neotectônica. Ao buscar balizar a aplicação de análise morfotectônica, em face do estado da arte das teorias e conceitos estudados pela Geomorfologia, observa-se que o conceito de neotectônica passa a ser de fundamental importância para a compreensão dos eventos ocorridos na área pesquisada. O conceito de neotectônica foi primeiramente definido por Obruchev (1948), no qual o termo se aplica aos movimentos tectônicos que ocorreram no fim do Paleógeno até o Quaternário e esses eventos exerciam um papel importante para a morfologia contemporânea. O termo neotectônica tem sofrido várias modificações e ao longo do séc. XX. Essas mudanças no conceito vão de acordo com o avanço das teorias de tectônica de placas e também com os estudos a respeito das ocorrências de neotectonismo (Vita-Finzi, 1986; Saadi, 1991; Morner, 1993). A relação entre a neotectônica e a geomorfologia é traduzida por muitos autores na atualidade, pela geomorfologia estrutural e estudos da Morfotectônica (resposta do relevo a eventos tectônicos), (Summerfield 1990 e 2000; Hancock, 1993; Suguio, 1999; Burbank e Anderson, 2011). A análise morfotectônica tem seus problemas, que consistem na distinção entre movimentos mais antigos e movimentos recentes (Verstappen, 1983). Assim, é necessária a identificação de feições morfotectônicas associadas a eventos mais jovens, como, depósitos superficiais deformados e o grau de juventude das formas criadas (facetas triangulares, escarpas abruptas sem dissecação) (Hiruma,1999; Hiruma, 2007; Gurgel et al., 2013).

Considerando esses conceitos, foi possível realizar a aplicação da análise morfotectônica a partir 
do imageamento remoto do Gráben do Cariatá. A área apresenta evidências de pulsações neocenozoicas, embora se localize em um contexto de margem passiva de continente, tradicionalmente tratado pela geomorfologia regional a partir da perspectiva erosiva/ denudacional (Ollier et al., 1985; Lidmar-Bergstrom et al., 2000; Japsen et al., 2006; Green et al., 2013). Não obstante, os setores planálticos do sudeste e nordeste do Brasil têm sido alvo de estudos recentes que enfocam a influencia da neotectônica sobre a morfogênese (morfotectônica) (Deffontaines, 1989; Mello, 1997; Hiruma, 1999; Silva, 1999, Morais Neto e Alkmin, 2001; Missura, 2005; Bezerra et al., 2008; Maia e Bezerra, 2011; Bezerra et al., 2011; Oliveira e Medeiros, 2012; Gurgel et al., 2013). Dentro desta perspectiva, faz-se necessário uma maior compreensão de como estes indicadores tectônicos podem trazer luz à definição dos controles estruturais sobre a sedimentação e compartimentação do gráben.

O Gráben do Cariatá (Figura 1) situa-se a 85 km do Recife, no sudeste do Estado da Paraíba, Nordeste do Brasil, com as coordenadas $35^{\circ} 20^{\prime} 30^{\prime \prime} \mathrm{W}$ e $7^{\circ} 20^{\prime} \mathrm{S}$ aproximadamente em sua porção central. Desde a sua identificação (Brito Neves et al., 2001 a, b), a unidade denominada Gráben do Cariatá deixou clara sua importância para a interpretação do cenário geomórfico e morfotectônico regional, desafiando algumas hipóteses pretéritas relacionadas à evolução geomorfológica do piemonte o Planalto da Borborema. Neste sentido, os estudos sobre a sedimentação neogênica e deformações tectônicas no referido gráben tem trazido novas respostas para a compreensão da história recente do relevo da área (Bezerra et al., 2008).

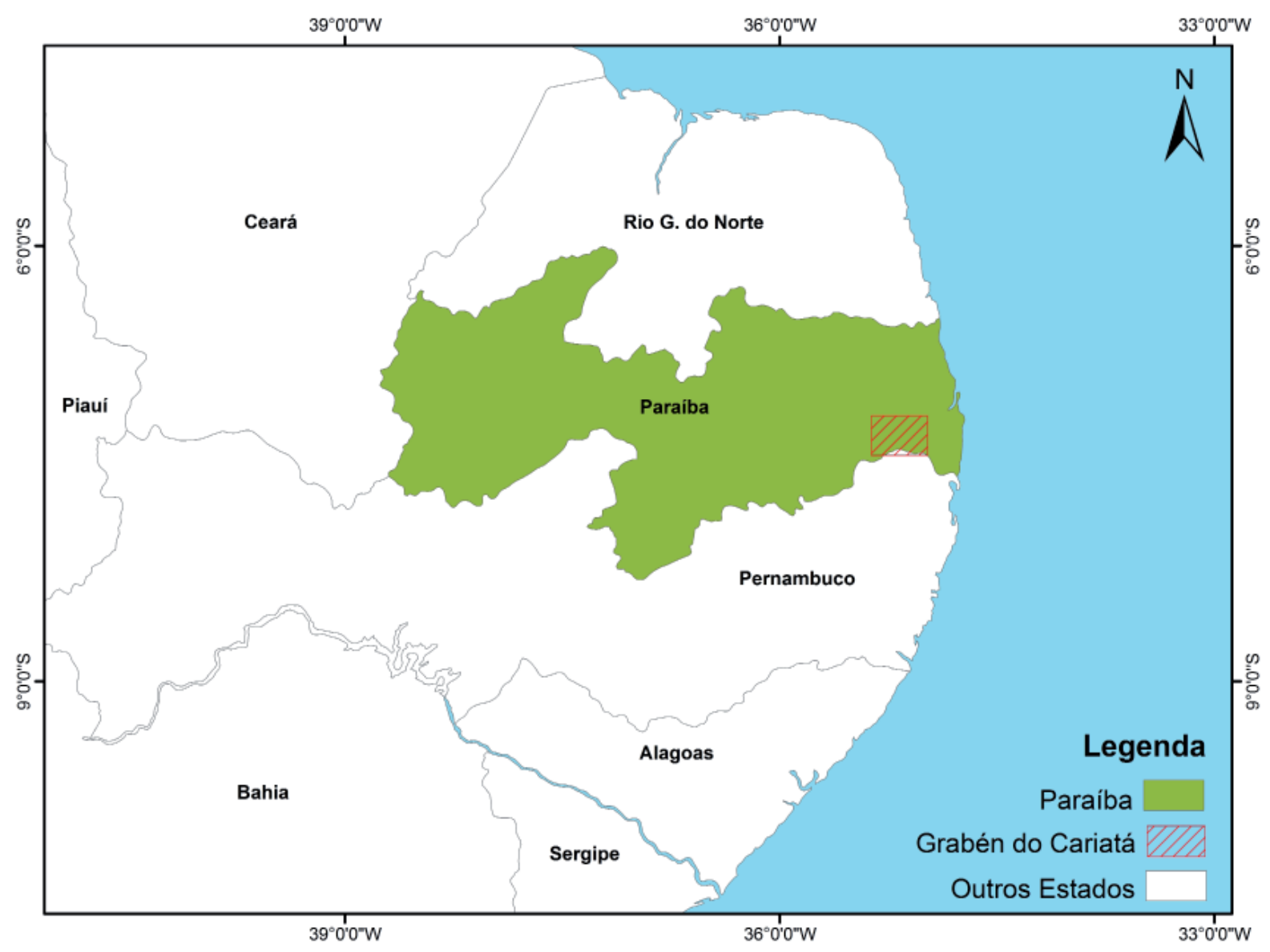

Figura 1 - Mapa de Localização do Gráben do Cariatá.

A utilização de imagens de satélite em conjunto com técnicas de sensoriamento remoto tem-se mostrado bastante útil para estudos geomorfológicos, com a ex- tração de fotolineamentos e a definição de unidades de relevo a partir da análise das formas e das combinações das bandas, o que possibilita uma melhor visualização 
das texturas e formas por meio das unidades de pixel (Chaves Jr. 1992; Mayer, 2000; Dragut e Blaschke, 2006; Blaschke e Kux, 2007; Florenzano, 2007; Saadat et al., 2008). Neste trabalho foram utilizadas estas técnicas para a identificação de feições morfotectônicas (Saadi, 1991; Saadi et al., 2004), tais como: facetas triangulares e trapezoidais (Wallace, 1978; Gurgel et al., 2013), anfiteatros de erosão (Hiruma, 1999, 2001 e 2007), vales assimétricos, vales lineares, capturas de drenagem, (Biancotti, 1979, Mikesell, et al., 2009, Maia et al., 2012) e Shutter Ridges (Cotton, 1948).

Utilizando sensoriamento remoto para avaliação do relevo em imagens SPOT e LANDSAT, Chaves Jr. (1992) e Florenzano (1993) afirmam que combinações das bandas infra-vermelho próximo e médio são mais indicadas para mapeamento de feições lineares e topográficas

O objetivo deste trabalho é realizar uma compartimentação geomorfológica e morfotectônicas do Gráben do Cariatá, mediada principalmente pela avaliação de imagens orbitais, estabelecendo uma relação entre superfície topográfica, materiais estruturadores e deformações neogênicas, evidenciadas a partir de morfoestruturas e seus depósitos superficiais correspondentes.

\section{Contexto Morfoestrutural}

O Gráben do Cariatá é delimitado ao norte pela falha normal de São José dos Ramos e ao sul pela falha normal de Camutanga, ambas com orientação NE-SW (Brito Neves et al., 2004) (Figura 2). Dois eventos de reativação neotectônica foram identificados na área, sendo que apenas um deles, o segundo, indicado como sendo do Pleistoceno Superior, reflete-se na deformação dos sedimentos que preenchem a referida fossa tectônica (Bezerra et al., 2008). O primeiro evento, pré-quaternário, afetou apenas o embasamento cristalino, sendo que a resposta de cada falha que estrutura o gráben foi diferente. A falha de Camutanga reativou a trama pré-cambriana. A reativação da falha de São José dos Ramos, ao contrário, atravessou a trama do embasamento cristalino pré-cambriano por meio de rupturas de rejeito direcional de direção NW-SE, dispostas perpendicularmente à mesma (Bezerra et al., 2008).

O Gráben do Cariatá se insere no contexto das faixas de milonitização que ocorrem entre os linea- mentos Patos e Pernambuco (Santos et al., 2002). O embasamento cristalino apresenta traços de foliação metamórfica de direção NE-SW, que acompanham o sentido geral das estruturas pré-cambrianas (lineamentos Patos e Pernambuco) e definem a própria orientação do gráben. Na porção leste do gráben, ocorre uma unidade edafoestratigráfica laterítica (Coberturas lateríticas), sobreposta ao embasamento cristalino (ortognaisses granodioríticos), correspondendo aos níveis mais elevados de dissecação no gráben, estruturando os tabuleiros desta poção da área de estudo (Tavares, 2007). Ainda na porção leste do gráben, os arenitos da formação Beberibe (Cretáceo) estruturam tabuleiros entrecortados por vales cuja orientação principal é subperpendicular à linha de costa. A região da Bacia Paraíba, adjacente ao Grabén do Cariatá, é marcada por extensos falhamentos com direção NE-SW (Barbosa e Lima Filho, 2005).

Na parte central do gráben, depósitos coluviais estruturam pequenos divisores tabulares com front voltado para a calha do rio Paraíba. Estes divisores possuem uma dissecação média à baixa (Tavares, 2007; 2010). Nestas unidades se fazem presentes duas litofácies distintas, o lamito (mud-flows) e o fluxo de detritos (debris flows). $\mathrm{O}$ lamito, que possui idades entre $160 \mathrm{Ka}$ e $28 \mathrm{Ka}$ (Bezerra et al., 2008), apresenta grãos pobremente selecionados devido à grande variação das partículas constituintes, ocorrendo ora partículas mais grossas, ora partículas mais finas (a granulometria varia de argila a cascalho). A esfericidade média e alta dos grãos, sugere que estes sedimentos sofreram transporte por distância moderada à alta. Esta unidade estrutura os topos tabulares. O fluxo de detritos, que possui idades entre $224 \mathrm{Ka}$ a $128 \mathrm{Ka}$ (Bezerra et al., 2008) apresenta um lamito conglomerático, com predominância de seixos de quartzo e quartzito. Estes se distribuem em uma matriz psamítico-pelítica, com poucos contatos dos seixos entre si. Estes seixos em geral são arrendondados e subangulosos. A matriz é composta por uma areia muito pobremente selecionada. O fluxo de detritos estrutura a base dos tabuleiros. Essa situação reflete o clima tropical semiárido, onde os depósitos são resultados dos processos como erosão laminar, com evacuação dos finos e fluxo de detritos de baixa viscosidade (Bezerra et al., 2008). As idades encontradas para os materiais que estruturam os tabuleiros são do Pleistoceno Médio com datas que variam entre 225 Ka e 20 Ka. (Bezerra et al., 2008). 


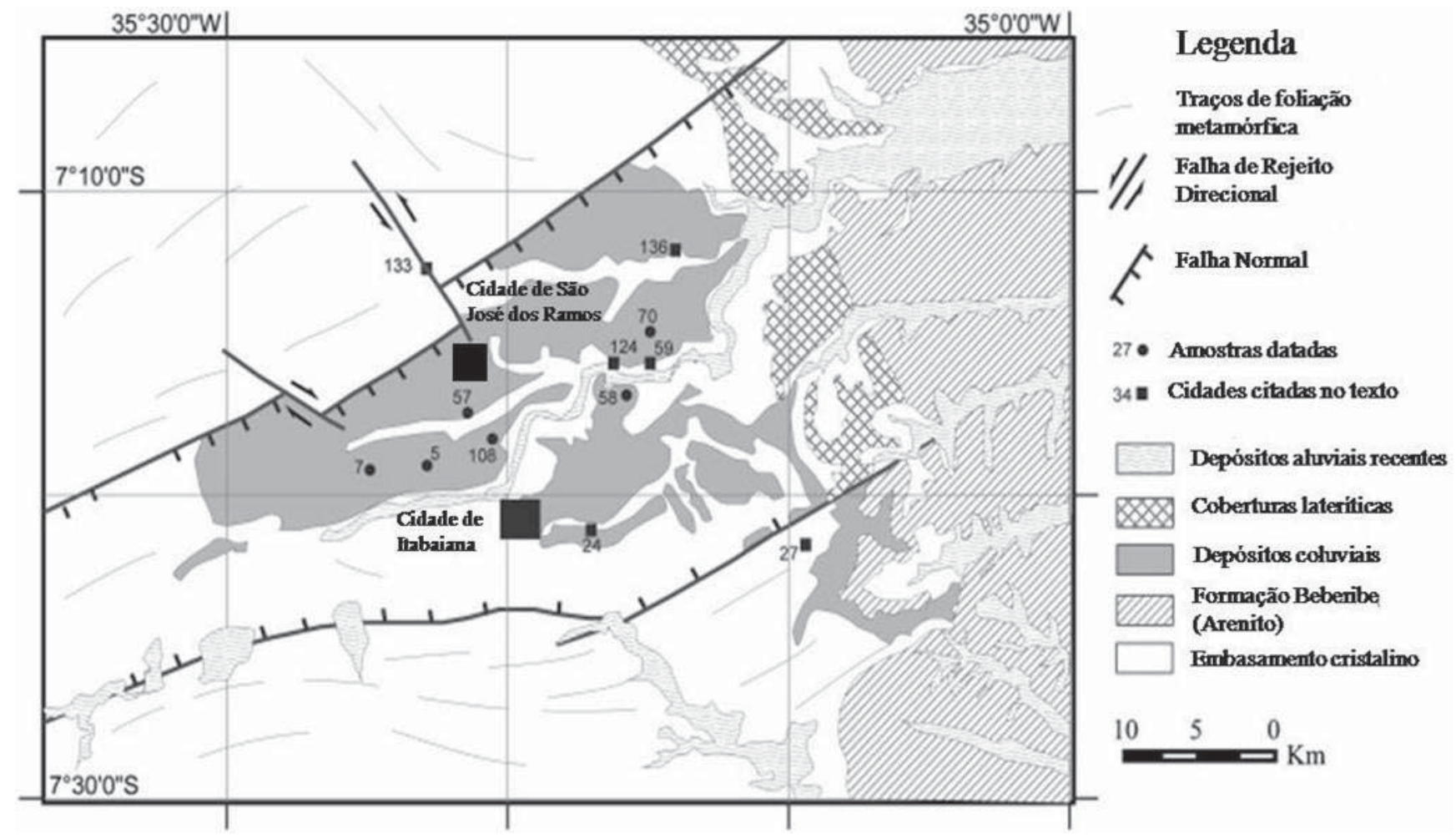

Figura 2 - Mapa Morfoestrutural do Gráben do Cariatá. (modificado de Bezerra et al., 2008.)

\section{Metodologia}

Mapeamento geomorfológico: O princípio para diferenciação de cada compartimento foi sua homogeneidade interna, isto é, o compartimento é delimitado quando se percebe que o conjunto de seus atributos (litologia, solos, declividade, etc.) é diferente do entorno e se constitui como alguma categoria de relevo que é considerada, tradicionalmente na literatura, como recorrente na região. O compartimento então definido é tratado como uma hipótese, que é testada com base na delimitação dos compartimentos do entorno e dos dados auxiliares (informações de campo). Assim, a construção do mapa é realizada através de uma reavaliação constante dos limites e propriedades dos compartimentos até a obtenção do mapa final. Este é um procedimento hipotético-dedutivo baseado em informações da literatura, da modelagem numérica do terreno e das visitas ao campo. As unidades então definidas receberam denominações conforme apresentadas em Guerra e Guerra (1997).

As informações da literatura são referentes aos compartimentos geomorfológicos e morfoestruturais já reconhecidos e à distribuição e caracterização das formações superficiais, tendo sido obtidas dos trabalhos de Tavares (2007) e Bezerra et al., (2008).

Os modelos numéricos foram extraídos a partir de imagens da Shuttle Radar Topography Mission (SRTM), com resolução espacial de 90m, referente à folha SB.25.Y-C (disponível em http://www.relevobr. cnpm.embrapa.br/download/index.htm). Neste trabalho, as informações utilizadas foram o modelo digital de elevação (MDE) e a distribuição de isoípsas extraídas do MDE em ambiente ArcGis, versão 9.3. Os planos de informação do MDE e das isoípsas foram correlacionados com dados temáticos de Geologia da folha Sapé, SC.25-Y-C-II (disponível em http://geobank.sa.cprm. gov.br/). O mapa geomorfológico foi confeccionado através da edição de vetores seguindo o raciocínio hipotético-dedutivo mencionado anteriormente.

Compartimentação morfotectônica: a análise morfotectônica foi baseada na identificação de anomalias geomorfológicas. Estas feições foram sugeridas primeiramente por Goy et al. (1991) e indicam a ocorrência de atividade neotectônica. Também foram analisadas feições associadas a falhamentos como facetas triangulares e trapezoidais (Wallace, 1978), Shutter Ridges (Cotton, 1948), escarpas (Stewart e Hancock, 1990; 1991), capturas de drenagem (Biancotti, 1979), 
depósitos superficiais deformados (Verstappen, 1983), anfiteatros de erosão, cristas, vales assimétricos e vales lineares. Para a identificação das feições morfotectônicas, foram utilizadas imagens de satélite do LANDSAT 5 TM, adquiridas através do site do INPE (Instituto Nacional de Pesquisas Espaciais) e manipuladas através do demonstrativo do software Erdas 9.3.

Foi realizada uma divisão por compartimentos do gráben, dividindo em setores Norte, Sul e Leste, de acordo com os atributos relevantes para compreensão da história geomorfológica e morfotectônica da área de estudo. Posteriormente foram identificadas feições morfotectônicas no software ArGis 9.3. Para a identificação das evidências deformacionais recentes fez-se uso de imagens LANDSAT 5 TM, ano de 2007. Foi feito um empilhamento de bandas 1 a 5 e 7 e a composição uti- lizada foi a 753, para assim poder visualizar as feições morfotectônicas, como capturas de drenagem, vales retilíneos, facetas triangulares e trapezoidais, cristas, anfiteatros de erosão, que foram identificadas segundo metodologia de Hiruma (1999) e Missura (2006).

\section{Resultados e Discussão}

\section{Compartimentação geomorfológica}

Foram identificadas sete unidades geomorfológicas (Figura 3): Maciços Residuais, Pedimentos, Tabuleiros Estruturados em Níveis de Crosta Laterítica, Tabuleiros Estruturados em Sedimentos Pleistocênicos, Transição Pedimento Rochoso; Detrítico/Tabuleiros Pleistocênicos; Tabuleiros Dissecados a Leste do Gráben, Terraços Fluviais e Plainos Aluviais.
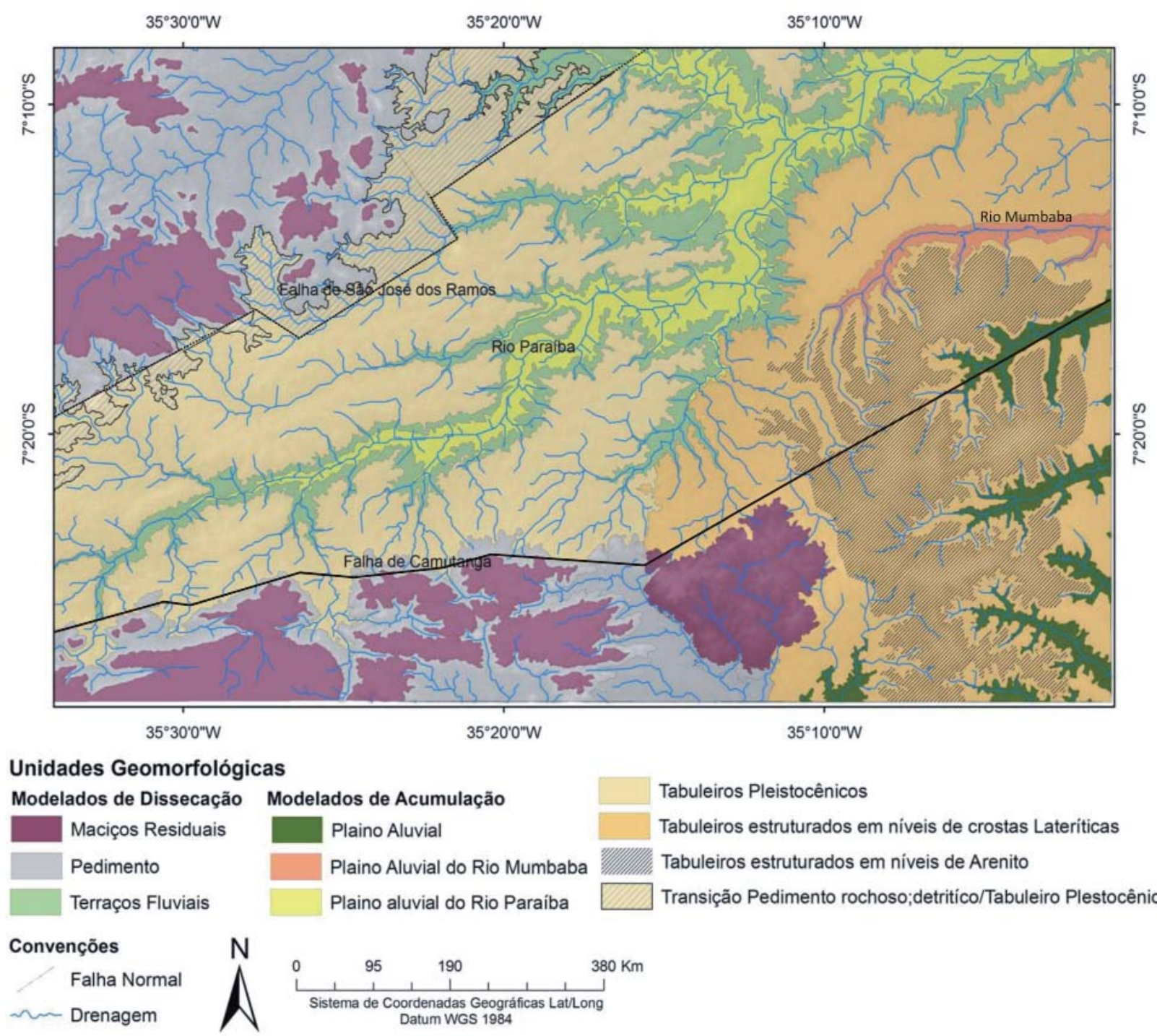

Figura 3 - Mapa Geomorfológico do Gráben do Cariatá. 
Maciços Residuais (Figura 4) - Localizados nos horst do Boqueirão e Manuel Mattos, esses maciços são os limites N-S do gráben do Cariatá. O horst do Boqueirão é sustentado por ortognaisses granodioríticos (Arqueano/Paleoproterozoico), se destacando na paisagem como um dos contrafortes do Planalto da Borborema, sob a forma de degraus que separam distintos patamares altimétricos em diversos estádios de dissecação. Com altitudes que se apresentam em torno dos 300 a $450 \mathrm{~m}$. Este compartimento tem a Falha de São José dos Ramos como o marcador estrutural e controla o recuo da escarpa dos maciços a norte. $\mathrm{O}$ horst Manuel Mattos se expressa sob a forma de um domo residual e dissecado como uma unidade alinhada ao sul, sendo o horst limitante. As altitudes nesta área variam de 300 a $650 \mathrm{~m}$. Esta unidade é formada por granitoides indiscriminados e é marcada pela falha de Camutanga. O cenário descrito antecede as superfícies regionais da Borborema stricto sensu, sob a forma de relevos residuais do tipo inselberg ou inselgebirge que se erguem como degraus de piemonte antecedendo as encostas do planalto.
Pedimentos (Figura 4) - Foram identificados dois níveis de pedimentos. Os pedimentos dissecados estão presentes na borda norte do gráben. São estruturados pelo embasamento cristalino e ocorrem ao longo do front de dissecação dos pequenos tabuleiros estruturados pelos sedimentos neogênicos. Esse modelado (pedimentos dissecados) caracteriza-se por apresentar uma zona de contato embasamento cristalino/sedimento marcado por um nível de eversão, sob a forma de uma superfície exumada. Os pedimentos dissecados são limitados ao sul pela falha de São José dos Ramos. A presença dessas feições é geralmente marcada pelo afloramento de zona saturada sob a forma de pequenos alagados e olhos d`gua. Na borda sul do gráben os pedimentos de caráter interplanáltico concentram-se ao nas proximidades do horst Manuel Mattos. Estes também são estruturados pelo embasamento cristalino e são marcados por amplos níveis pedimentares, pouco dissecados, sem cobertura sedimentar neógena, que transitam para os maciços residuais ao sul formando encostas de perfil côncavo-planar.

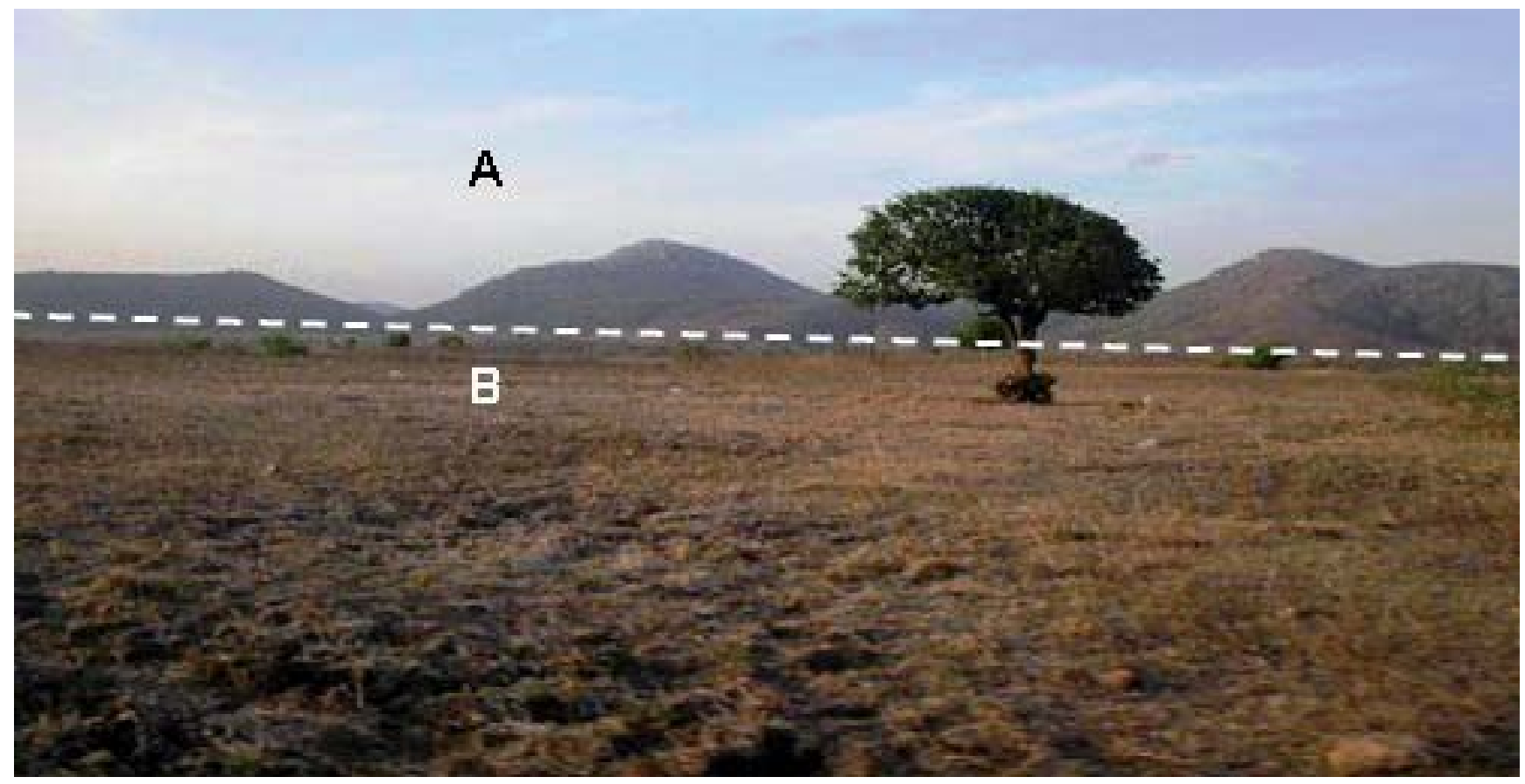

Figura 4 - Maciços residuais (A) e pedimentos (B) no horst do Boqueirão, próximo à cidade de São José dos Ramos (fonte: Bruno Tavares, 2005).

Transição Pedimento rochoso; detrítico/Tabuleiros Pleistocênicos (Figura 5) - Localizada na borda norte do gráben, esta transição não apresenta um limite bem demarcado na paisagem. Nesta seção do gráben o pedimento rochoso e o detrítico se expressam sob a forma de uma rampa sentido N-S. Esta rampa atravessa perpendicularmente a falha de São José dos Ramos (falha que controla a sedimentação na margem esquerda do 
rio Paraíba) em direção aos tabuleiros pleistocênicos. Os níveis de altimetria nesta área ficam em torno dos 110 a $120 \mathrm{~m}$. Esta diferença entre as cotas altimétricas, que não é abrupta, subverte assim a relação direta entre hipsometria e idade das superfícies, e a necessidade da geração de uma superfície erosiva a montante da área de acumulação (glacis de deposição). Neste caso têm-se duas superfícies de idades distintas e com os mesmos níveis altimétricos.
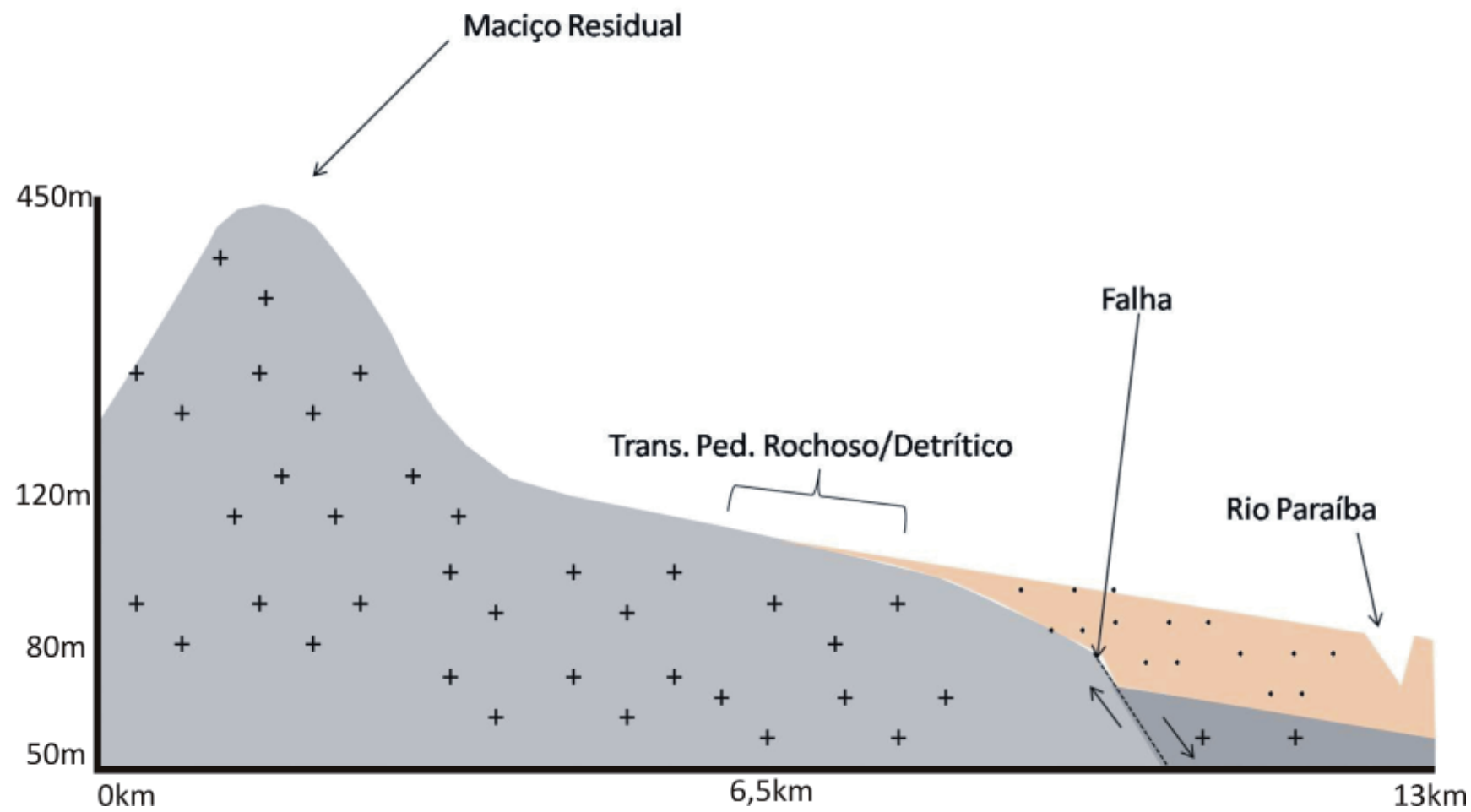

Figura 5 - Perfil geomorfológico esquemático da Transição Pedimento rochoso; detrítico/Tabuleiros Pleistocênicos.

Tabuleiros Estruturados em Sedimentos pleistocênicos (Figura 6) - Estas unidades ocorrem confinadas no gráben, tendo o front voltado para a calha do rio Paraíba. Os topos dos tabuleiros são bem preservados, ligeiramente convexos. O material do topo é arenoso, favorecendo a infiltração de água em relação ao escoamento. A infiltração é evidenciada pela eluviação da argila e consequente formação de horizontes arenosos neste patamar. Os pequenos divisores tabulares apresentam cotas altimétricas em torno de 70 a $120 \mathrm{~m}$ e são estruturados por duas litofácies distintas: o fluxo de detritos como unidade basal e o lamito como unidade do topo tabular (Figura 7). A unidade basal (fluxo de detritos) é uma litofácie com cascalheira matriz suportada. A unidade do topo (lamito) se consitui como sedimentos inconsolidados, característicos de corrida de lama (BEZERRA et al., 2008), sendo areno-argilosos, mal-selecionados com ocorrência de cascalhos e pequenos seixos. Estas litofácies datam do Pleistoceno Superior. O lamito apresenta idades de $22 \mathrm{Ka}$ até os $109 \mathrm{Ka}$, e o fluxo de detritos tem idades que variam dos 128 Ka até os 224 Ka. Estes depósitos estão relacionados com oscilações climáticas no Quaternário, estando a sua gênese ligada ao clima (Bezerra et al., 2008). Os tabuleiros de um modo geral se apresentam como leques deposicionais, que com a coalescência formam pequenos alvéolos de circundenudação.

Tabuleiros Dissecados a leste do gráben (Figura 8 e 9) - Dois tipos de unidades estruturam os topos tabulares nesta área do gráben. Primeiro, há ocorrência de tabuleiros estruturados por sedimentos cretáceos (Santoniano/Campaniano) da Formação Beberibe (Figura 8), formados por arenitos com grãos angulosos e irregulares de cor esbranquiçada creme a cinza. Alguns afloramentos desta formação a leste do gráben revelam níveis mais silicatados que chegam localmente a for- 
mar cornijas sobre alvéolos semi-circulares ativamente esculpidos pela drenagem de primeira ordem. A ocorrência destes sedimentos da Bacia Paraíba (Cretáceo-Cenozoico) a leste do gráben, atinge cotas altimétricas superiores a 200 m e constituem uma forte evidência de ocorrência de flexura na borda leste da área de estudo, uma vez que o arenito da Formação Beberibe, unidade basal da bacia PB, ocorre na superfície. Os tabuleiros estruturados em crosta laterítica (Figura 9) constituem uma superfície estrutural, controlada pelo afloramento de uma unidade pedoestratigráfica, remanescentes tabulares de crosta laterítica e sobrepostos diretamente

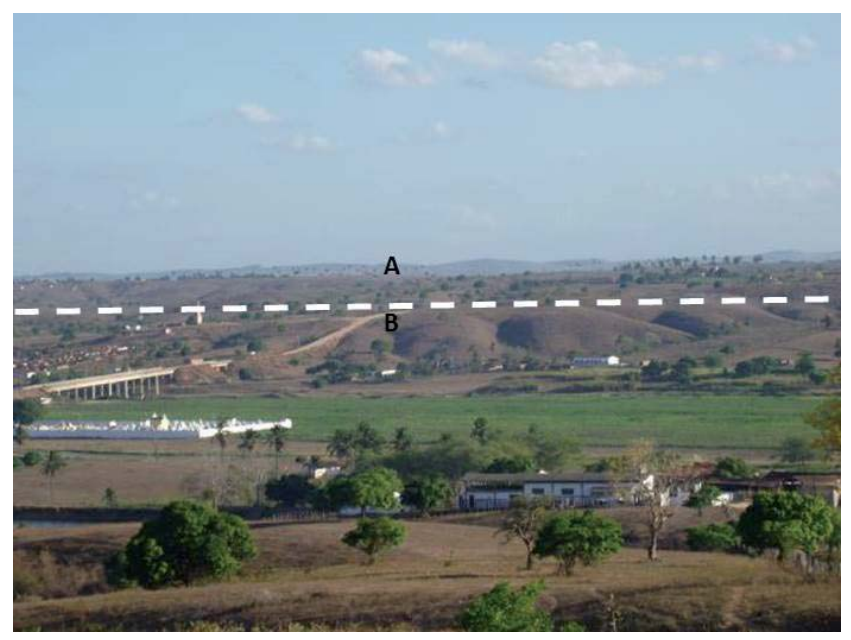

Figura 6 - Tabuleiros estruturados em sedimentos pleistocênicos. Lamito (a) e Fluxo de detrito (b). Município de Pilar - PB. Fonte: Bruno Tavares, 2005.

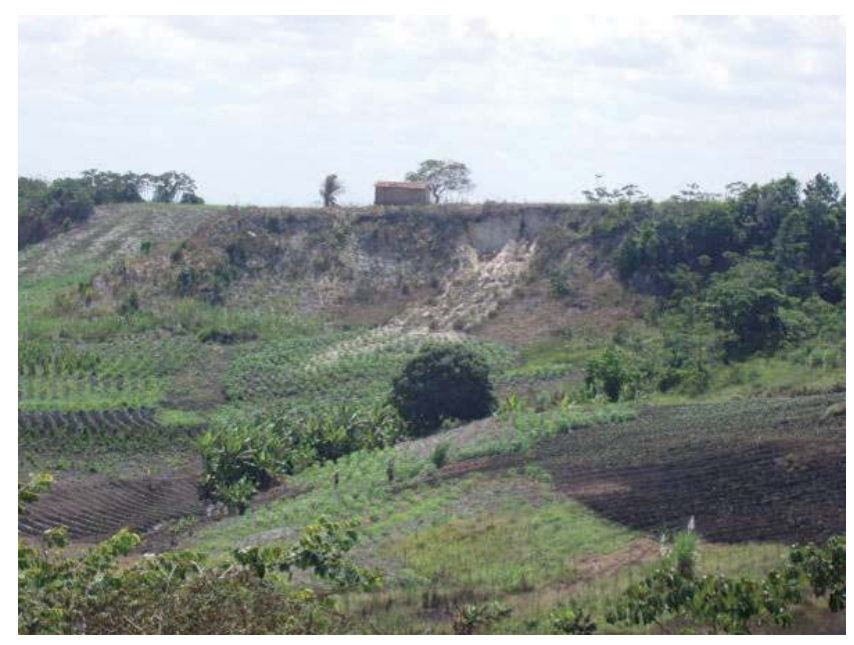

Figura 8 - Tabuleiros estruturados sobre Fm. Beberibe. Fonte: Bruno Tavares, 2005. ao embasamento cristalino exumado. A presença desses níveis de ferricrete em superfície corrobora com a dinâmica de soerguimento do bordo leste do gráben, que neste trecho está destituído até mesmo do capeamento sedimentar cretáceo (Formação Beberibe). A dissolução da crosta dá origem a um solo podzólico, havendo sido observado que em vários trechos a crosta encontra-se bastante intemperizada. Em imagens de satélite LANDSAT 7, esta unidade pode ser facilmente confundida com os tabuleiros costeiros comumente associados à Formação Barreiras.

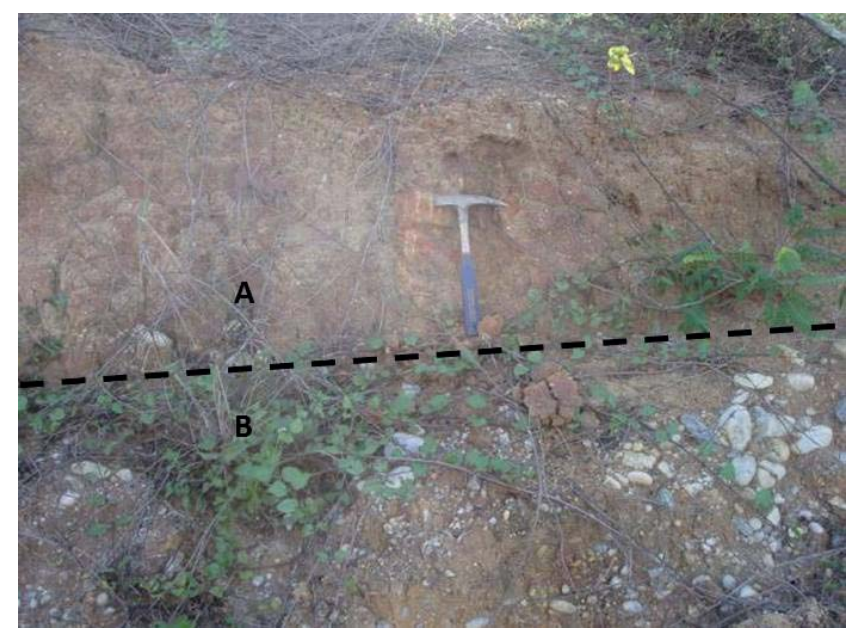

Figura 7 - Contato entre lamito (a) e fluxo de detritos (b). Município de Itabaiana - PB. Fonte: Bruno Tavares, 2005.

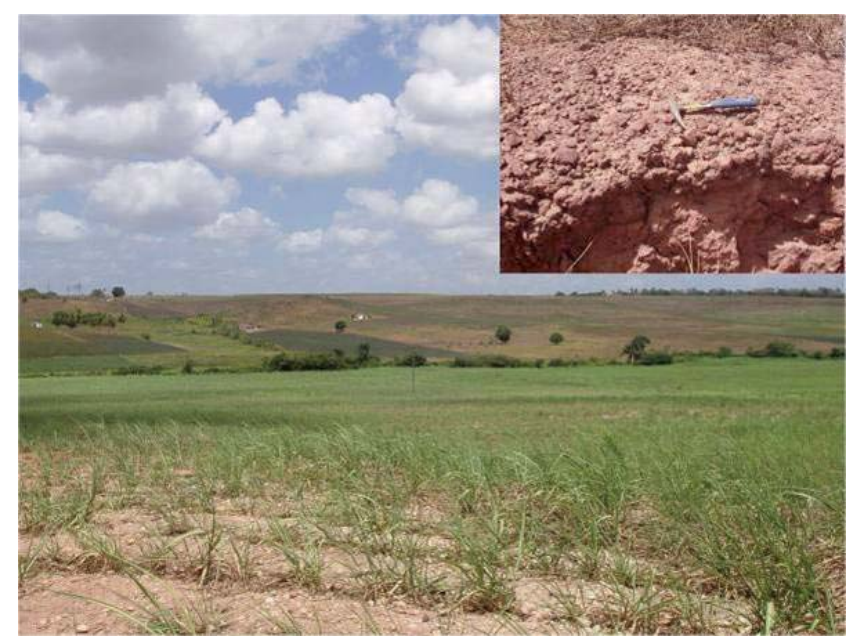

Figura 9 - Tabuleiros estruturados em níveis de crosta laterítica, Inset: Couraça ferruginosa. Fonte: Bruno Tavares, 2009. 
Plainos Aluviais (Figura 10a) - Referem-se às áreas baixas e planas ao longo do vale do Rio Paraíba (Figura 10) e dos outros principais rios, como o Mumbaba (Figura 11). O relevo suave indica que os sedimentos são mais arenosos e depositados pelo próprio rio (depósitos aluviais). Este compartimento transita lateralmente para uma superfície de eversão de aspecto pediplanizado. Nos plainos do rio Paraíba (nível de base local), há ocorrência de extensas barras arenosas, e muita sedimentação associada a barramentos na drenagem.

O baixo curso do rio Paraíba, mostra-se profundamente influenciado pelo gráben do Cariatá. O curso deste rio à montante do gráben era de orientação aproximadamente N-S, mas foi bruscamente capturado no sentido de inverter a direção do curso de E-W, em continuação para o rio Mumbaba, para N-S, infletindo mais adiante novamente para E-W. O rio Mumbaba capturou

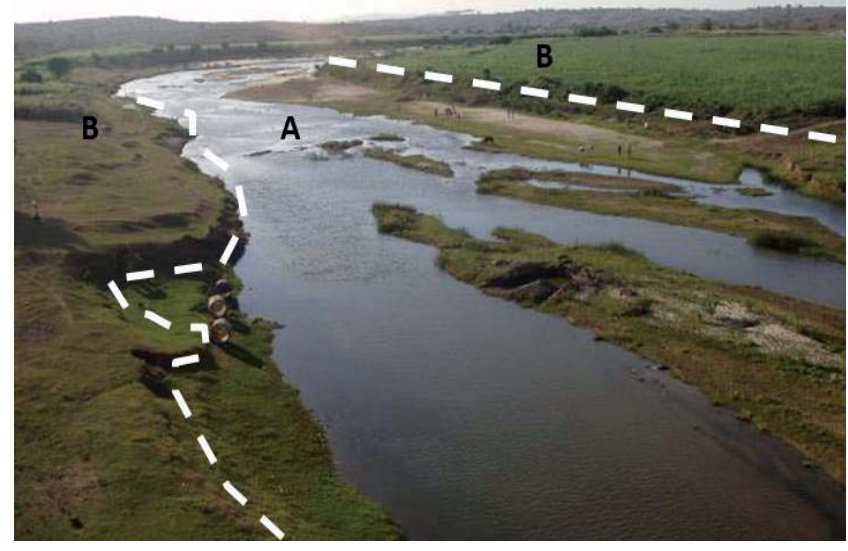

Figura 10 - Rio Paraíba apresentando plainos com muita sedimentação (A) e terraços marginais (B). Fonte: Bruno Tavares, 2005.

\section{Compartimentação morfotectônica}

A partir da elaboração do mapa de compartimentos morfotectônicos (Figura 12) foi possível identificar várias anomalias geomorfológicas de acordo com a metodologia sugerida por Goy et al., (1991). As anomalias referidas indicam a ocorrência de atividade neotectônica. As feições encontradas foram escarpas de falha e lineamentos; depósitos superficiais deformados; capturas de drenagem; anfiteatros de erosão; cristas e vales lineares e facetas triangulares e trapezoidais ao longo das encostas. o antigo vale do rio Paraíba, no momento que este teve o seu curso invertido para o sentido N-S.

O que podemos encontrar na área de captura, é um rio de pequenas proporções, e um extenso vale. Isso evidencia que o vale no qual o rio Mumbaba se encontra atualmente foi outrora do rio Paraíba.

Terraços Fluviais (Figura 10B) - Os terraços dos rios principais (rio Paraíba e rio Mumbaba) apresentam vários níveis escalonados, o que, é mais visível no antigo vale do rio Paraíba, onde se encontra o atual curso do rio Mumbaba. Nesta área os terraços evidenciam um contínuo rebaixamento de nível de base da região. O material estruturador é composto por uma cascalheira matriz suportada com presença de crosta laterítica e com ocorrência de mosqueamento (indicador de mudança do nível freático) em todos os terraços.

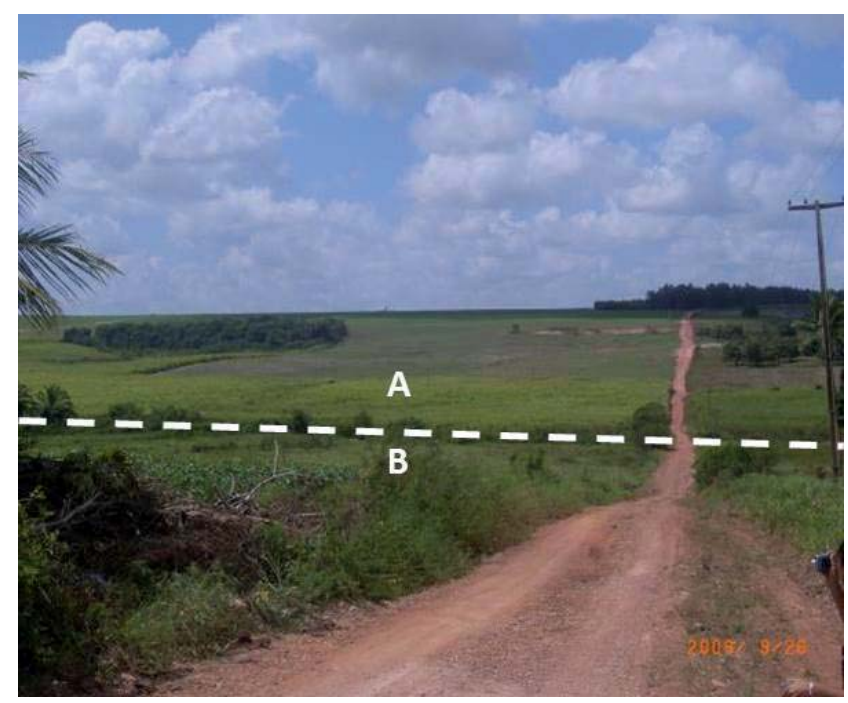

Figura 11 - Rio Mumbaba (tracejado). Margens (Ae B). Adimensão do vale é incompatível com sua dinâmica atual. Fonte: Bruno Tavares, 2009.

Para melhor visualização e interpretação do mapa morfotectônico, o mesmo foi dividido em três compartimentos: Horst do Boqueirão, Horst Manuel Mattos e Zona de Captura.

Horst do Boqueirão (Figura 13) - A borda norte do gráben está sob o contexto dos pedimentos dissecados e piemontes que antecedem o Planalto da Borborema. Nesta área foram encontradas evidências de um forte recuo da escarpa controlada pela falha normal de São José dos Ramos de direção NE-SW. Nessa área ocorre uma faixa milonítica e brechas de falha, que são 


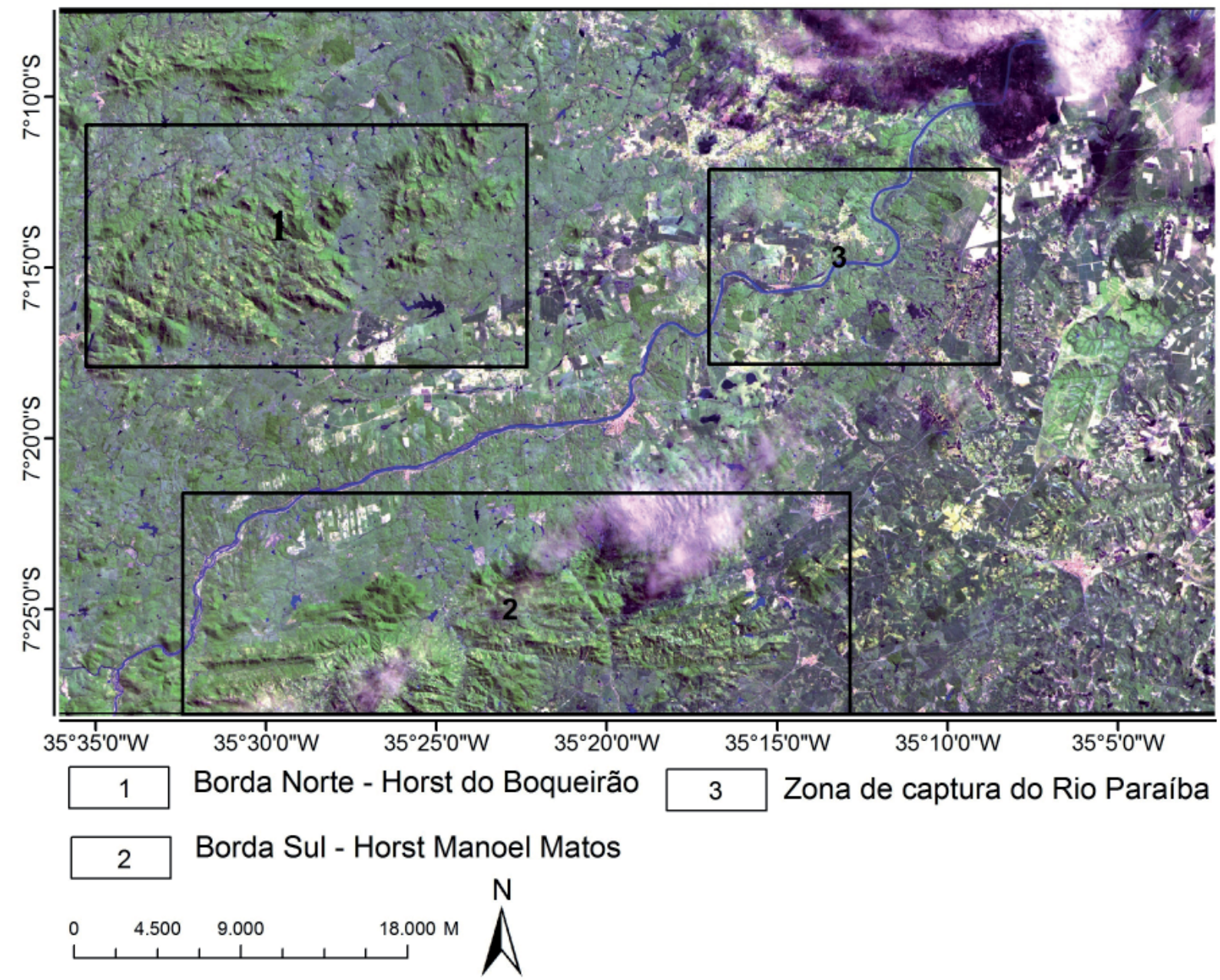

Figura 12 - Compartimentação Morfotectônicos do Gráben do Cariatá.

bastante susceptíveis a erosão, facilitando a formação de vales retilíneos. Esta falha controla a sedimentação neogênica confinada no gráben, além de constituir o seu limite extremo setentrional. O recuo da escarpa do horst neste setor é marcado pela ocorrência de diversas facetas trapezoidais e triangulares na base dos maciços residuais que ocorrem na área, indicando ainda que a posição da superfície contemporânea da escarpa evoluiu de forma remontante a partir da falha. Os anfiteatros de erosão que ocorrem nestes maciços sob a forma de cabeceiras em alvéolos sugerem que estas foram prováveis áreas fontes dos sedimentos que recobrem os pequenos divisores tabulares confinados no gráben (lamito). Esta unidade litoestratigráfica está ligada a picos de intensa precipitação ocorridos durante o último estadial (Bezerra et al., 2008). Os vales lineares apresentam-se concordantes à direção geral do relevo, indicando um controle da estrutura sobre a rede de drenagem local. Com a análise dos lineamentos de relevo de drenagem podemos observar uma concordância entre a direção de lineamentos de relevo e drenagem.

Horst Manuel Mattos (Figura14) - O Horst Manuel Mattos, borda sul do Graben, é limitado pela falha de Camutanga, um zona de cizalhamento transcorrente dextral. Não há presença de facetas triangulares ou trapezoidais nesta borda. O recuo da escarpa não é tão intenso em relação ao limite norte do gráben. As rochas que estruturam o horst sul fazem parte do complexo Sertânia, uma unidade metassedimentar e metavulcânica, característica do Terreno Alto Moxotó (Brito Neves et al., 2004). Trata-se de uma sequência eminentemente metapelítica de grau metamórfico médio e forte, sendo extremamente migmatizada (Santos et al., 2002). Outra unidade que se faz presente é o complexo gnáissico-migmatítico, onde ocorrem ortognaisses tonalíticos e granodioríticos paleoproterozóicos, mas retrabalhados no Meso e Neoproterozoico. Nesse contexto estrutural, há um controle evidente das unidades metassedimen- 


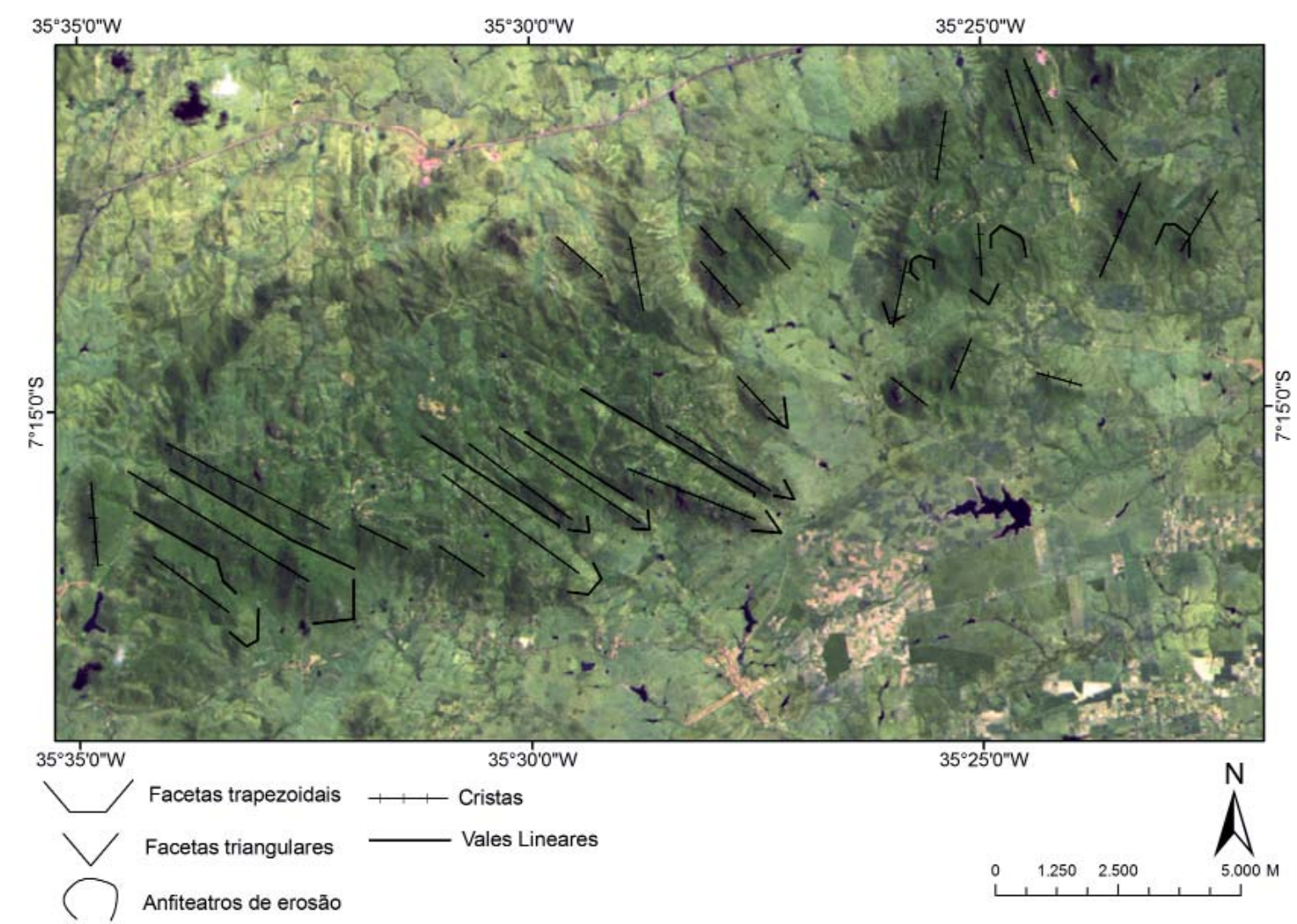

Figura 13 - Horst do Boqueirão, na borda norte do Gráben: nota-se a concentração de vales retilíneos. O recuo da linha de falha é evidenciado pelas facetas triangulares e trapezoidais.

tares e do complexo Sertânia sobre o recuo da escarpa do horst sul. Neste setor ocorrem longas cristas e as mesmas coincidem com o trend regional das faixas de cisalhamento de direção E-W. No entanto os vales encontrados na área cortam o relevo na direção N-S, dissecando ativamente as cristas e encostas de direção E-W. A drenagem encaixada nesses vales se apresenta de forma obsequente, a controlar a exumação dos sedimentos que estruturam os tabuleiros. Vale ainda ressaltar que grande parte da sedimentação neógena na margem direita do rio Paraíba foi evacuada.

\section{Zona de Captura do Rio Paraíba (Figura 15)} - Os sistemas fluviais são bastante sensíveis a movimentos crustais, podendo ocorrer migração de canais, rios em gancho, formação de lagos marginais. Nesta área há várias ocorrências de captura de drenagem por parte do coletor principal da área, o rio Paraíba. No trecho imediatamente a montante do gráben a direção principal do rio é N-S, invertendo-se bruscamente para E-W na área deste estudo. Nas áreas próximas às capturas observa-se o bloqueio das drenagens laterais que demandam o Paraíba provavelmente em função da maior taxa de sedimentação ao longo do eixo principal da planície. A resposta hidrológica deste bloqueio é a formação de lagoas e áreas de drenagem impedida com afloramento dos níveis freáticos. Nas proximidades da cidade de São Miguel de Itaipu ocorre à captura mais notável do rio Paraíba, sendo possível observar na paisagem a ocorrência de um boqueirão de vento sobre-elevado por onde antes passava a calha do rio no sentido leste. A jusante da captura o antigo vale do rio Paraíba permaneceu com direção E-W agora ocupado pelo rio Mumbaba, de pequena extensão longitudinal e baixa vazão. A nascente do Mumbaba ocorre próxima a um vale suspenso (boqueirão de vento), a jusante da qual já se estabelece uma planície com mais de $100 \mathrm{~m}$ de largura. Neste trecho observam-se ainda terraços escalonados bastante desconectados em altimetria do nível contemporâneo da calha do Mumbaba. Este evidente rebaixamento do nível de base a leste da inflexão do Paraíba pode ter sido uma das causas da mudança de orientação no seu curso. 


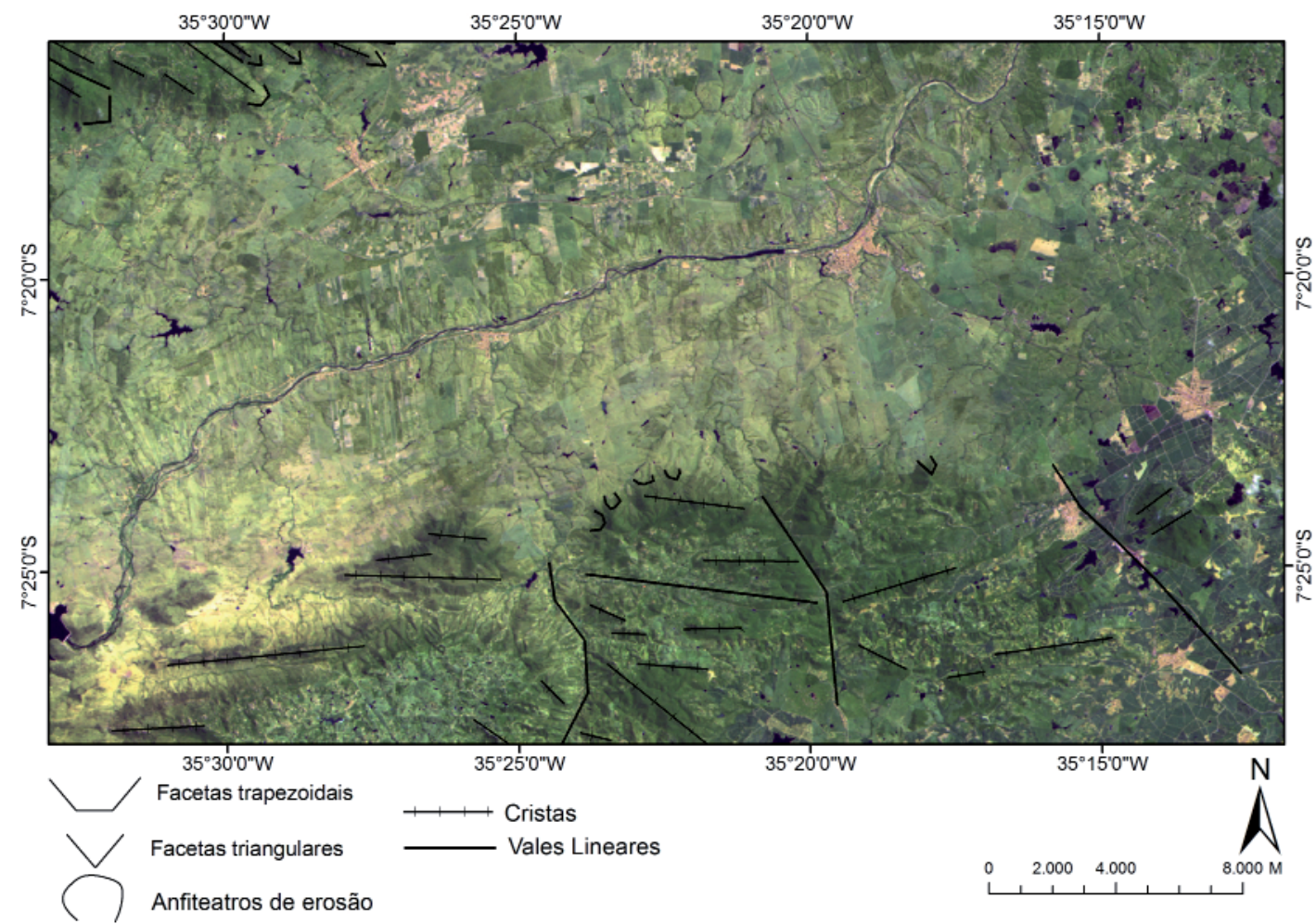

Figura 14 - Horst Manuel Mattos, na borda sul do Gráben, não há um forte recuo da escarpa nesse setor por conta de um controle das rochas que sustentam o horst sul.

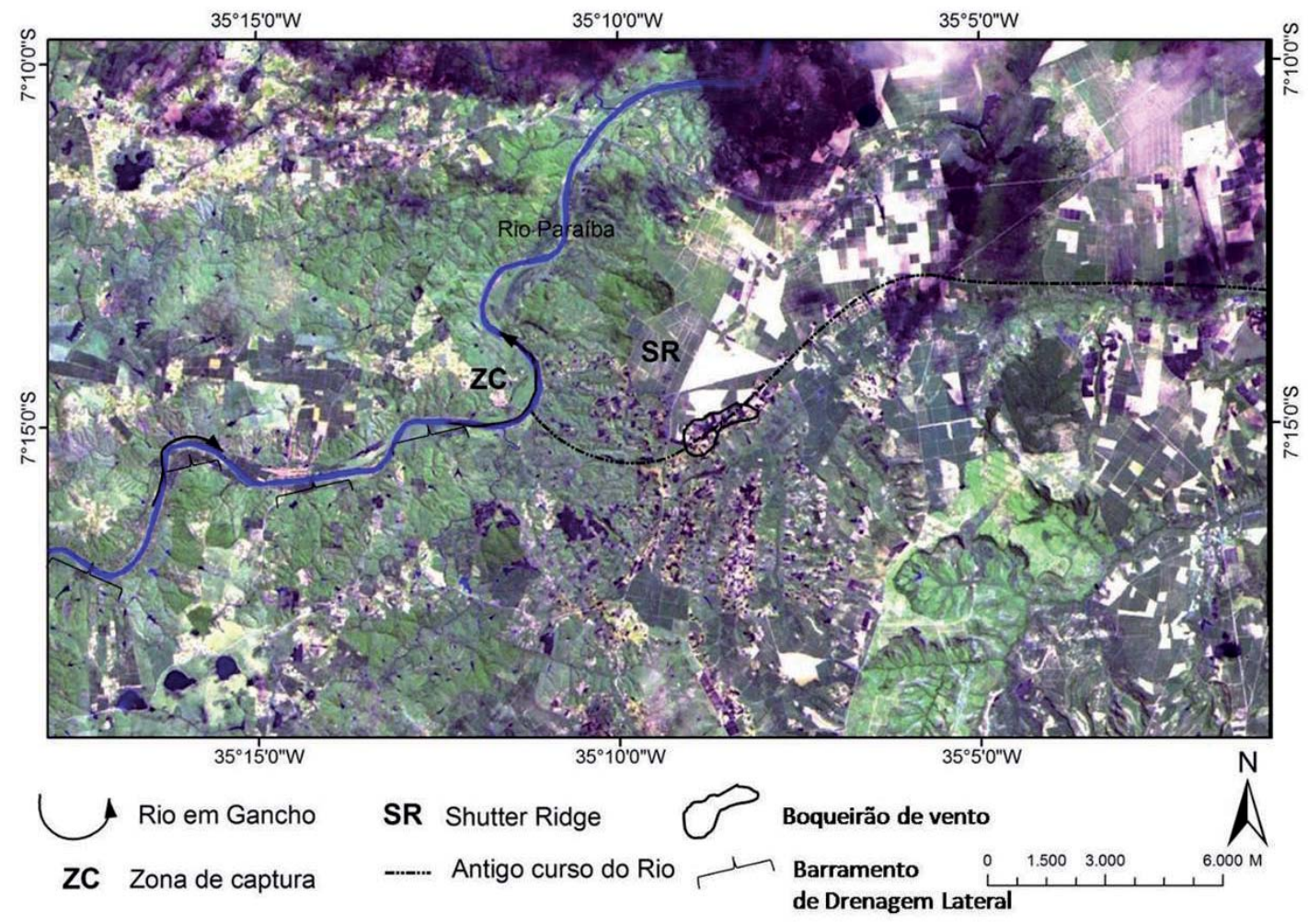

Figura 15 - Zona de captura da drenagem do rio Paraíba. Presença de vários barramentos da drenagem por conta da alta taxa de sedimentação ao longo do eixo principal da planície. Destaque para a captura do coletor principal, o rio Paraíba, e sua antiga planície atuando como um boqueirão de vento. 


\section{Conclusões}

A aplicação conjunta de MDE’s e imagens de satélite propiciaram uma modelagem mais fidedigna da área de estudo, constituindo-se assim em uma importante ferramenta para a análise da influência da neotectônica sobre os compartimentos do relevo a partir da elaboração das feições morfotectônicas.

Desta forma, tais feições como escarpas, facetas triangulares e trapezoidais, anfiteatros de erosão e vales lineares identificadas a partir das técnicas empregadas podem estar estritamente correlacionadas à reativação de falhas no Gráben - falhas normais e transcorrentes controlando a deposição e disposição dos sedimentos na superfície do terreno. A rede de drenagem principal da área de estudo, o rio Paraíba, também está influenciada pela dinâmica morfotectônica, o que se faz explicitar a partir de uma incisão de maior ordem em determinados setores, resultando mesmo no abandono da antiga planície sob a forma de terraços erosivos.

\section{Referências Bibliográficas}

BEZERRA, F. H. R., BRITO NEVES, B. B.; CORRÊA, A.C.B., BARRETO, A.M.F., SUGUIO, K. Late Pleistocene tectonicgeomorphological development within a passive margin - The Cariata trough, northeastern Brazil. Geomorphology, v.97. p.555-582. 2008.

BEZERRA, F.H.R., DO NASCIMENTO, A.F., FERREIRA, J.M., NOGUEIRA, F.C., FUCK, R.A., NEVES, B.B.B., SOUSA, M.O.L. Review of active faults in the Borborema Province, intraplate South America integration of seismological and paleoseismological data. Tectonophysics 510, 269-290. 2011.

BIANCOTTI A. Rapporti fra morfologia e tettonica nella pianura cuneese. Geografia Fisicia e Dinâmica Quaternária, v.2. p.51-56. 1979 .

BLASCHKE, T. \& KUX, H. Sensoriamento remoto e SIG avançados. 2.ed. São Paulo: Oficina de Textos. 304 p. 2007.

BRITO NEVES, B. B., CAMPOS NETO, M.C., VAN SCHMUS, W.R., SANTOS, E.J. O sistema Pajeú-Paraíba e o maciço São José do Campestre no leste da Borborema. Revista Brasileira de Geociências, v. 31. p. 1-15. 2001a.

BRITO NEVES, B. B., CAMPOS NETO, M.C., VAN SCHMUS, W.R., FERNANDES, T.M.G., SOUZA, S. O terreno alto Moxotó no leste da Paraíba (maciço Caldas Brandão). Revista Brasileira de Geociências, v. 31. p.16-31. 2001b.
BRITO NEVES, B. B., RICCOMINI, C., FERANDES, T.M.G., SANT’ANNA, L.G. O sistema tafrogênico Terciário do saliente oriental nordestino na Paraíba: um legado Proterozócio. Revista Brasileira de Geociências. v.34. n.1. p.127-134. 2004.

BROWN, R.W., GALLACHER, K., GLEADOW, A.J.M., SUMMERFIELD, M.A. Morphotectonic evolution of the South Atlantic margins of Africa and South America. In: M.A. SUMMERFIELD (ed) Geomorphology and Global Tectonics. West Sussex: Wiley, p.255-282. 2000.

BURBANK, D.; ANDERSON, R. Tectonic Geomorphology. Blackwell. 2ed. 2011. p.472.

CHAVES JR, P.S. Comparison of spatial variability in visible and near-infrared spectral images. Photogrammetric Engineering and Remote Sensing. v.58. n.7. p.957-964. 1992.

CORRÊA, A. C., BARRETO, A.M.F., BEZERRA, F. H. R., BRITO NEVES, B. B.; SUGUIO, K. Análise geomorfológica e sedimentológica do gráben de Cariatá, Paraíba. In: $X$ Congresso da Abequa. Anais de Trabalhos Completos. Guarapari, p.4147. 2005.

COTTON C. A. Landscape - as developed by the processes of normal erosion. 2 ed. New York: John Wiley \& Sons, 1948. 509 p.

DEFFONTAINES, B. Proposition of a morphoneotectonic method: application in the Fougères area. Oriental Britany, France. Bulletin INQUA - Neotectonic Comission. v.12. p.48-52. 1989.

DOORNKAMP, J. C. Geomorphological approaches to the study of neotectonics. Journal of the Geological Society. v.143. p.335-345. 1986.

DRAGUT, L. \& BLASCHKE, T. Automated classification of landform elements using object-based image analysis. Geomorphology. v.81. p.330-344. 2006.

FLORENZANO, T.G. In: FLORENZANO, T.G. (org.) Geomorfologia: conceitos e tecnologias atuais. São Paulo: Oficina de textos, 2007. p.36-72.

GOY, J.L., SILVA, P.G., ZAZO, C., BARDAJI, T., SOMOZA, L. Model of morphoneotectonic map and legend. - Neotectonic Comission. 14: p.19-31. 1991.

GREEN, P.F., LIDMAR-BERGSTRÖM, K., JAPSEN, P., BONOW, J.M., CHALMERS, J.A. Stratigraphic landscape analysis, thermochronology and the episodic development of elevated, passive continental margins. Geological Survey of Denmark and Greenland Bulletin 2013/30, 150 pp. 2013. 
GURGEL, S.P.P., BEZERRA, F. H. R.; CORRÊA, A. C. B.; MARQUES, F. O.; MAIA, R. P. Cenozoic uplift and erosion of structural landforms in NE Brazil, Geomorphology, p.68-84. 2013.

HIRUMA, S.T. Neotectônica no Planalto de Campos de Jordão, SP. Dissertação (Mestrado em Geologia Sedimentar). Instituto de Geociências - USP. São Paulo. 102p. 1999.

HIRUMA, S.T. Significado tectônico dos planaltos isolados da Bocaina. Universidade de São Paulo, Tese de doutorado. São Paulo, 205p. 2007.

JAPSEN, P., BONOW, M.B., GREEN, P.F., CHALMERS, J.A., LIDMAR-BERGSTRÖM, K.Elevated, passive continental margins: long-term highs or Neogene uplifts? New evidence from West Greenland. Earth and Planetary Science Letters 248, 330-339. 2006.

LIDMAR-BERGSTRÖM, K., OLLIER, C.D., SULEBAK, J.R. Landforms and uplift history of southern Norway. Global and Planetary Change 24, 211-231. 2000.

MABESOONE, J. M.; CASTRO, C. Desenvolvimento Geomorfológico do nordeste brasileiro. B. Soc. Geol. Núcleo Nordeste, v.3, p.5-36, 1975.

MAIA, R. P. ; BEZERRA, F. H. R.Geomorfologia e Neotectônica da Bacia Hidrográfica do Rio Apodi-Mossoró Ne/Brasil. Mercator (Fortaleza. Online), v. 11, p. 209-228, 2012.

MAYER, L. Application of digital elevation models to macroscale tectonic geomorphology. In: M.A. SUMMERFIELD (ed) Geomorphology and Global Tectonics. West Sussex: Wiley, p.15-28. 2000.

MELLO, C. L. Sedimentação e tectônica cenozóicas no Médio Vale do Rio Doce (MG, Sudeste do Brasil) e suas implicações na evolução de um sistema de lagos. Tese (Doutorado em Geologia Sedimentar). Instituto de Geociências - USP. São Paulo. 275p. 1997.

MISSURA, R. Análise morfoestratigráfica da bacia do Ribeirão dos Poncianos-MG. Dissertação (Mestrado em Geografia). UNESP. Rio Claro. 136p. 2006.

MORAIS NETO, J. M. \& ALKMIM, F. F. A deformação das coberturas terciárias do Planalto da Borborema (PB-RN) e seu significado tectônico. Revista Brasileira de Geociências 31(1). p.95-106. 2001.

MÖRNER, N. Neotectonics, the new global tectonic regime during the last $3 \mathrm{Ma}$ and the initiation of Ice Ages. Anais da Academia Brasileira de Ciências, 65(Supl. 2): 295-301. 1993.
MUTZENBERG, D. S., TAVARES, B.A.C., CORRÊA, A.C.B. $A$ influência controles estruturais sobre a morfogênese e a sedimentação neógena na bacia do Rio Carnaúba (RN) e sua aplicação aos estudos geoarqueológicos do Seridó. Clio Arqueológica N 19 - Vol.2, 2005.

OBRUCHEV, V. A. Osnovnye cherty kinetiki i plastiki neotektoniki. Akad. Nauk. SXSSR Izv. Serv. Geol., 5:13-24. 1948.

OLIVEIRA, R. G DE; MEDEIROS, W. E. Evidences of buried loads in the base of the crust of Borborema Plateau (NE Brazil) from Bouguer admittance estimates. Journal of South American Earth Sciences V. 37 p.60-76, 2012.

OLLIER, C.D. Morphotectonics of continental margins with great escarpments In: MORISAWA, M. \& HACK, J.T. (ed.) Tectonic Geomorphology. Boston: Allen \& Unwin, 1985. p.3-25.

OLLIER, C.D. Morphotectonics of passive continental margins: Introduction. Z. Geomorphol. Suppl., 54: 1-9, 1985.

SAADAT, H., BONNELL, R., SHARIFI, F., MEHUYS,G., NAMDAR, M., ALE-EBRAHIM, S. Landform classification from a digital elevation model and satellite imagery. Geomorphology. v.100. p.453-464. 2008.

SAADI, A. Ensaio sobre a morfotectônica de Minas Gerais: tensões intra-placa, descontinuidades crustais e morfogênese. Tese para cargo de Professor Titular. Instituto de Geociências. UFMG. Belo Horizonte. 285 p. 1991.

SANTOS, E. J. (org.) Geologia e recursos minerais do Estado da Paraíba. Recife: Ministério de minas e energia, 234p. 2002.

SILVA, T. M., MELLO, C.L., CARMO, I.O., MOURA, J.R.S. Relief compartments in the middle valley of Paraíba do Sul river and other neighboring mountainous areas (southeastern Brazilian plateau), morphotectonics relationships. In: GEOVEC 99 IGU-GERTEC Meeting (IGU/UFRJ). Rio de Janeiro. p.40. 1999.

STEWART I.S. \& HANCOCK P.L. What is a fault scarp? Episodes, 13(4): p.256-263. 1990.

STEWART I.S. \& Hancock P.L. Neotectonics. In: P.L.HANCOCK (ed.), Continental deformation. Oxford: Pergamon, 1994. p.370-409.

SUGUIO, K. Geologia do quaternário e mudanças ambientais: passado + presente $=$ futuro ? São Paulo: Paulo’s comunicação e Artes gráficas, 1999. 366p.

SUMMERFIELD, M.A. Geomorphology and Global 
Tavares B. A. C. et al.

Tectonics. West Sussex: Wiley, 2000. 367p.

TAVARES, B.A.C. Análise dos controles estruturais sobre a compartimentação geomorfológica e a sedimentação neógena no gráben do Cariatá, PB. Monografia (Graduação Bacharelado em Geografia), UFPE: Recife, 2007.

VERSTAPPEN, H.T. Applied geomorphology. Amsterdam:
Elsevier, 1983. 437p.

VITA-FINZI, C. Recent earth movements: An introduction to neotectonics. London-Orlando: Academic Press: 1986. 226p.

WALLACE R.E. Geometry and rates of change of faultgenerated range fronts, North-Central Nevada. Journal of Research of the U.S. Geological Survey, 6(5): p.637-650. 1978. 